\title{
PENINGKATAN PEMAHAMAN KEPADA CALON JAKSA TERHADAP KEBIJAKAN HUKUM PIDANA DI BIDANG LINGKUNGAN HIDUP
}

\author{
Ade Adhari ${ }^{1}$, Neysa Tania ${ }^{2}$ dan Hans Poliman ${ }^{3}$ \\ ${ }^{1,2,2}$ Fakultas Hukum, Universitas Tarumanagara, Jakarta \\ ${ }^{1}$ Surel: adea@fh.untar.ac.id
}

\begin{abstract}
The environment is a public interest that must be guarded and protected by the state. One form of protection provided by the state is through the mechanism of the criminal justice system. In carrying out this system, prosecutors play an important role in prosecuting cases in the environmental field. Therefore, an understanding of criminal law policies in the environmental field is important. This time the provision of understanding on criminal law policies in the environmental field was given to prospective prosecutors through classes held by the Education and Training Agency of the Attorney General's Office of the Republic of Indonesia. This activity is carried out using zoom media. The lecture method was chosen as part of the way to carry out community service activities this time. In addition to the lecture, at the end of the session, a question-and-answer discussion was held and a test session was held for each participant. This is done to obtain information whether the participants have understood the material that has been given. This level of understanding needs to be known as an indicator of increasing environmental law awareness among prospective prosecutors. After giving the material, the prospective prosecutors will get an increased understanding of the offense in the environmental field, the criminal sanctions that can be imposed on the offense and how to prosecute the offense.
\end{abstract}

Keywords: Environment, penal policy, prosecutor

\begin{abstract}
ABSTRAK
Lingkungan hidup merupakan kepentingan publik yang harus dijaga dan dilindungi oleh negara. Salah satu bentuk perlindungan yang diberikan oleh negara adalah melalui mekanisme sistem peradilan pidana. Dalam memainkan sistem tersebut, jaksa memegang peranan penting dalam melakukan penuntutan terhadap perkara di bidang lingkungan hidup. Oleh sebab itu, pemahaman tentang kebijakan hukum pidana di bidang lingkungan hidup menjadi penting. Pemberian pemahaman mengenai kebijakan hukum pidana di bidang lingkungan hidup kali ini diberikan kepada para calon jaksa melalui kelas yang diadakan oleh Badan Pendidikan dan Pelatihan Kejaksaan Republik Indonesia. Kegiatan ini dilakukan dengan menggunakan media zoom. Metode ceramah dipilih sebagai bagian dari cara melaksanakan kegiatan pengabdian kepada masyarakat kali ini. Selain ceramah, diakhir sesi diadakan kegiatan diskusi tanya-jawab dan adanya sesi ujian bagi setiap peserta. Hal ini dilakukan untuk mendapatkan informasi apakah para peserta telah memahami materi yang telah diberikan. Tingkat pemahaman tersebut perlu diketahui sebagai bahan penilaian indicator meningkatnya kesadaran hukum lingkungan diantara para calon jaksa. Setelah pemberian materi selesai dilakukan para calon jaksa mendapatkan peningkatan pemahaman terkait dengan delik di bidang lingkungan hidup, sanksi pidana yang dapat dikenakan terhadap delik tersebut dan bagaimana melakukan tindakan penuntutan terhadap delik tersebut.
\end{abstract}

Kata Kunci: Lingkungan, kebijakan hukum pidana, jaksa

\section{PENDAHULUAN}

Lingkungan hidup beserta sumber daya alam yang ada di dalamnya merupakan anugerah yang diberikan oleh Tuhan Yang Maha Esa. Anugerah tersebut merupakan pemberian Tuhan YME kepada semua makhluk hidup, dan tidak hanya terbatas untuk manusia. Lingkungan hidup yang baik dan sehat bagian yang inherent alias melekat pada diri manusia, karena merupakan bagian dari hak asasi manusia (human rights). Dalam pandangan HAM, setiap orang tanpa terkecuali, memiliki hak hidup sejahtera lahir dan batin, bertempat tinggal dan mendapatkan lingkungan hidup yang baik dan sehat. Hal tersebut secara konstitusional dijamin oleh Pasal 28H UndangUndang Dasar Negara Republik Indonesia Tahun 1945 (UUD NRI 1945). Dengan perkataan lain ha katas lingkungan hidup bukan hanya sebagai human rights melainkan juga constitutional rights. 
Pasal 28H UUD NRI 1945 merupakan wujud dalam ranah das sollen (yang seharusnya). Hal yang seharusnya tersebut berbanding terbalik dengan apa yang ada dikenyataan (das sein). Hal ini dapat diamati apabila melihat kondisi lingkungan Indonesia saat ini yang semakin terancam karena "faktor alam, iklim dan cuaca dan aktivitas manusia yang dilakukan demi kepentingan ekonomi" (Sufiyatidan dan Munsyarif, 2017). Kepentingan atau tuntutan ekonomi (economic interest) dengan demikian dapat dikatakan sebagai penyebab utama kondisi lingkungan semakin memburuk. Demi mengejar kejayaan secara ekonomi, banyak pihak yang melakukan tindakan yang merusak dan mencemari lingkungan. Pencemaran dan kerusakan lingungan yang terjadi sekaligus menunjukkan Indonesia masih kesulitan dalam menjaga kelestarian hidup yang baik dan sehat. Namun yang pasti, kerusakan dan pencamaran lingkungan berdampak negatif bagi kelangsungan hidup manusia.

Sebagai bentuk "kewajiban negara dan tugas pemerintah untuk melindungi segenap sumbersumber daya alam Indonesia" sesuai dengan Pasal 33 UUD NRI 1945, maka negara, berkewajiban untuk melakukan perlindungan dan pengelolaan lingkungan hidup dalam pelaksanaan pembangunan berkelanjutan agar lingkungan hidup Indonesia dapat tetap menjadi sumber dan penunjang hidup bagi rakyat Indonesia serta makhluk hidup lain (Penjelasan UU PPLH). Ketentuan tersebut membawa konsekuensi sebagai titik awal ketetapan konstitusional dalam sistem kenegaraan Indonesia yang menjadi dasar acuan untuk perlindungan terhadap lingkungan hidup di Indonesia. Oleh karena itu, pemerintah mengambil langkah dengan membuat kebijakan hukum sebagai pedoman penegakan hukum lingkungan.

Pada tahun 2009 pemerintah telah menetapkan Undang-Undang Nomor 32 Tahun 2009 tentang Perlindungan dan Pengelolaan Lingkungan Hidup (UU PPLH). Dalam UU PPLH terdapat penguatan dimana prinsip-prinsip perlindungan dan pengelolaan lingkungan hidup yang didasarkan pada tata kelola pemerintahan yang baik dengan penanggulangan dan penegakan hukum yang mewajibkan pengintegrasian aspek transparansi, partisipasi, akuntabilitas dan keadilan (Sodikin, 2010). Keberadaan UU PPLH pada prinsipnya salah satunya dimaksudkan memberikan perlindungan terhadap lingkungan hidup.

Perlindungan lingkungan hidup yang dilakukan oleh UU PPLH, dilakukan melalui ketentuan pidana yang dapat digunakan untuk menjadi dasar pemidanaan oleh aparat penegak hukum, salah satunya oleh jaksa. Dalam undang-undang tersebut diatur berbagai perbuatan yang dikualifikasi sebagai delik di bidang lingkungan hidup, subjek yang dapat dipertanggungjawabkan, dan sanksi pidana yang dapat dikenakan terhadap para pelanggar. Jaksa dengan demikian dapat dikatakan sebagai aparat penegak hukum lingkungan. Perlindungan terhadap lingkungan hidup menjadi salah satu tanggung jawab jaksa sebagaimana diamanatkan dalam peraturan perundang-undangan. Atas dasar hal tersebut dilakukan kegiatan pengabdian kepada masyarakat yang memberikan pemahaman seputar lingkungan hidup dan kebijakan hukum pidana dalam memberikan perlindungan terhadap lingkungan hidup.

\section{METODE PELAKSANAAN PKM}

Pelaksanaan pengabdian kepada masyarakat di Balai Diklat Kejaksaan Republik Indonesia diselenggarakan melalui berbagai tahapan sebagai berikut: Pertama, Tahapan Penggalian Informasi Permasalahan, penggalian permasalahan kebijakan hukum pidana di bidang lingkungan hidup dilakukan melalui membaca data-data primer yaitu Undang-Undang, data sekunder yaitu buku, jurnal, artikel, maupun media internet. Kedua, Tahapan Penyusunan Proposal, penyusunan proposal dilakukan untuk memberikan gambaran kepada mitra mengenai kegiatan pengabdian kepada masyarakat yang akan dilakukan oleh Pengusul. Ketiga, Tahapan Pengurusan Izin Pelaksanaan PKM, Pengurusan perizinan dilakukan sesuai dengan prosedur atau peraturan pihak mitra yaitu Balai Diklat Kejaksaan Republik Indonesia dengan tetap mematuhi peraturan kesehatan yang dikeluarkan oleh Pemerintah. Keempat, Tahapan Pelaksanaan PKM, 
Pelaksanaan perizinan dilakukan secara daring melalui salah satu platform seperti zoom dengan topik "Kebijakan Hukum Pidana di Bidang Lingkungan Hidup." Kelima, Tahapan Penyusunan Luaran PKM, Sebagai luaran PKM akan dibuat suatu artikel mengenai topik yang bersangkutan yang akan dipresentasikan dalam seminar nasional Senapemas 2021. Keenam, Tahapan Laporan Kemajuan PKM, Penyusunan laporan kemajuan PKM berisi mengenai progres pelaksanaan PKM sebagai informasi kepada pihak LPPM Untar. Ketujuh, Tahapan Penyusunan Laporan Akhir PKM, penyusunan laporan akhir berisi keseluruhan pelaksanaan kegiatan PKM serta hasil PKM serta pertanggungjawaban pelaksanaan oleh pelaksana kepada Pihak LPPM Untar.

Dalam kegiatan pelaksanaan pengabdian kepada masyarakat di Balai Diklat Kejaksaan Republik Indonesia, partisipasi mitra dalam berbagai bentuk sebagai berikut: a. Menyampaikan informasi tentang adanya pelaksanaan pengabdian kepada masyarakat di Balai Diklat Kejaksaan Republik Indonesia; b. Mengadakan koordinasi dengan ketua pelaksana Balai Diklat Kejaksaan Republik Indonesia untuk mengikuti kegiatan pengabdian kepada masyarakat; dan c. Menyusun absensi yang dibutuhkan pada saat pelaksanaan pengabdian kepada masyarakat di Balai Diklat Kejaksaan Republik Indonesia.

\section{HASIL DAN PEMBAHASAN}

Pelaksanaan kegiatan pengabdian kepada masyarakat telah dilaksanakan kepada para calon jaksa. Berikut adalah bukti pelaksanaan kegiatan:

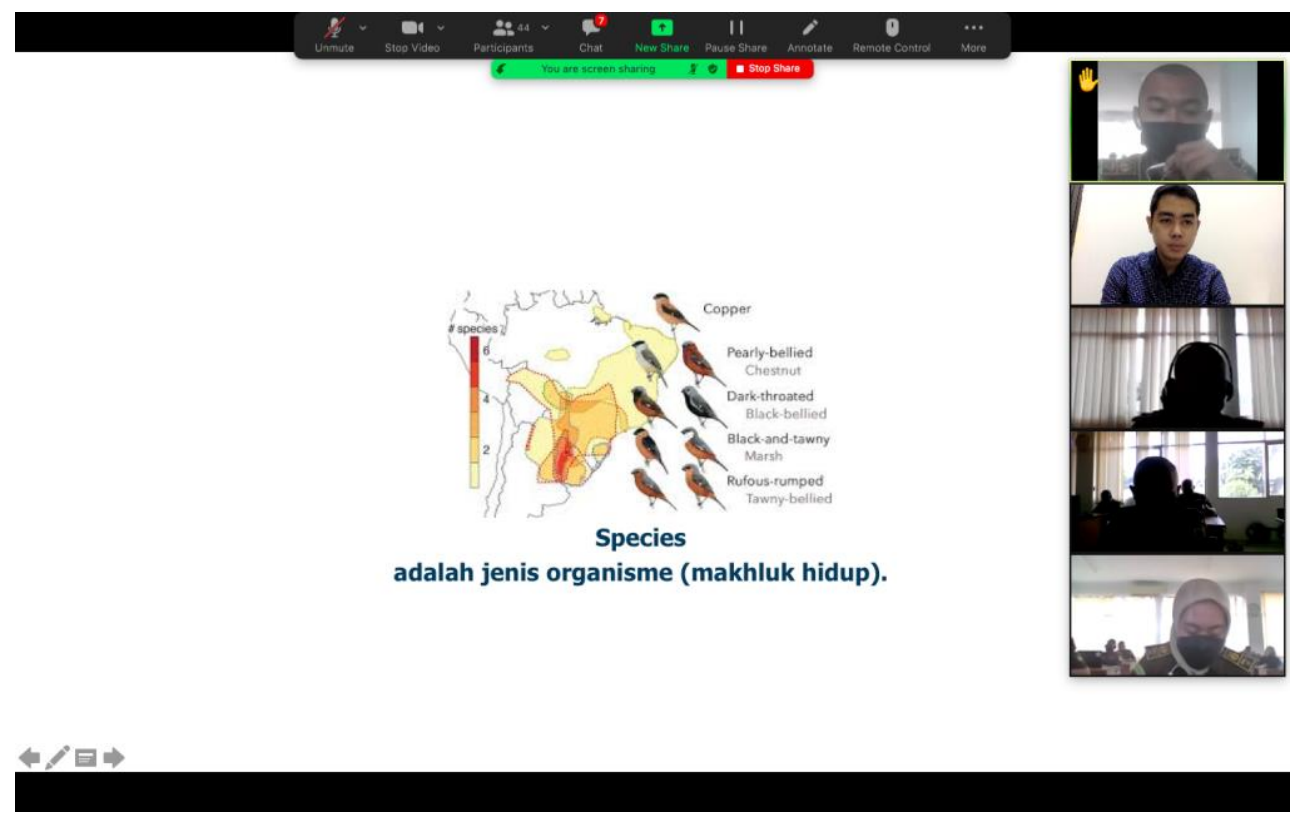

Gambar 1. Pelaksanaan PKM

Dalam kegiatan pengabdian kepada masyarakat kali ini, secara umum pelaksana pengabdian kepada masyarakat menjelaskan kebijakan hukum pidana di bidang lingkungan hidup kepada para calon jaksa. UU PPLH di dalamnya memuat banyak norma hukum, baik norma perlindungan maupun pengelolaan lingkungan hidup. Salah satu norma utama yang diatur dalam undang-undang tersebut adalah ketentuan perlindungan terhadap lingkungan hidup. Terdapat banyak ketentuan yang dibuat dengan maksud untuk memberikan perlindungan, salah satunya adalah ketentuan pidana. Pada saat UU PPLH menetapkan adanya ketentuan pidana, maka ini menjadi kewenangan aparat penegak hukum. Sebagai aparat penegak hukum, dengan demikian Jaksa diberikan kewenangan oleh UU PPLH untuk menegakan hukum terhadap setiap pelanggaran hukum yang terjadi. 
Jaksa dalam hal ini berwenang menindak pelanggaran terhadap tindak pidana di bidang lingkungan hidup. Takdir Rahmadi di dalam bukunya mengemukakan perihal pengertian dari tindak pidana lingkungan. Tindak pidana tersebut diartikan sebagai segala perintah dan larangan undang-undang kepada subjek hukum yang jika dilanggar diancam dengan penjatuhan sanksi pidana, dengan tujuan untuk melindungi lingkungan hidup secara keseluruhan ataupun unsurunsur dalam lingkungan hidup seperti hutan satwa, lahan, udara dan air, serta manusia. Oleh karena itu, dengan pengertian ini, tindak pidana lingkungan hidup tidak hanya mengenai ketentuan-ketentuan pidana yang dirumuskan dalam UU PPLH tetapi juga ketentuan-ketentuan pidana yang dirumuskan dalam peraturan perundang-undangan lain sepanjang rumusan ketentuan itu ditujukan untuk melindungi lingkungan hidup secara keseluruhan atau bagianbagiannya (Takdir Rahmadi, 2014). Apa yang dikemukakan oleh Takdir Rahmadi memperjelas bahwa tindak pidana di bidang lingkungan hidup mencakup delik yang begitu luas, tidak terbatas pada segala perbuatan yang diancam dalam ketentuan pidana di UU PPLH, akan tetapi di berbagai undang-undang diluar UU PPLH sepanjang mengatur ketentuan pidana sepanjang rumusan ketentuan itu ditujukan untuk melindungi lingkungan hidup secara keseluruhan atau bagian-bagiannya. Dengan demikian, ketentuan pidana di bidang panas bumi, minyak dan gas bumi, pertambangan mineral dan batubara, dan lain sebagainya termasuk delik di bidang lingkungan hidup.

Di dalam UU PPLH terdapat delik dibidang lingkungan hidup. Delik tersebut ada yang dirumuskan dengan delik materiil dan delik formil. Delik formil adalah "delik yang menitikberatkan pada tindakan" sedangkan delik materiil adalah "delik yang menitikberatkan pada akibat" (Eddy O.S. Hiariej, 2016). Komposisinya berbagai delik materiil dan formil sebagaimana dikemukakan tersebut dapat terlihat dalam tabel dibawah ini:

Tabel 1. Delik Materiil dan Delik Formil dalam UU PPLH

\begin{tabular}{ll}
\hline \multicolumn{1}{c}{ Rumusan Delik Materiil } & \multicolumn{1}{c}{ Rumusan Delik Formil } \\
\hline Pasal 98 ayat (1) & Pasal 100 ayat (1) \\
Pasal 98 ayat (2) & Pasal 101 \\
Pasal 98 ayat (3) & Pasal 102 \\
Pasal 99 ayat (1) & Pasal 103 \\
Pasal 99 ayat (2) & Pasal 104 \\
Pasal 99 ayat (3) & Pasal 105 \\
Pasal 112 & Pasal 106 \\
& Pasal 107 \\
& Pasal 108 \\
& Pasal 109 \\
& Pasal 110 \\
& Pasal 111 ayat (1) \\
& Pasal 111 ayat (2) \\
& Pasal 113 \\
& Pasal 114 \\
& Pasal 115 \\
\hline
\end{tabular}

Berbagai perbuatan yang dilarang dan dirumuskan dalam delik materiil secara umum berisi berbagai tindak pidana sebagaimana diuraikan dibawah ini:

"perbuatan yang mengakibatkan dilampauinya baku mutu udara ambien, baku mutu air, baku mutu air laut, atau kriteria baku kerusakan lingkungan hidup; perbuatan yang mengakibatkan dilampauinya baku mutu udara ambien, baku mutu air, baku mutu air laut, atau kriteria baku 
kerusakan lingkungan hidup dan mengakibatkan orang luka dan/atau bahaya bagi kesehatan manusia; perbuatan yang mengakibatkan dilampauinya baku mutu udara ambien, baku mutu air, baku mutu air laut, atau kriteria baku kerusakan lingkungan hidup dan mengakibatkan orang luka berat atau mati; dansengaja tidak melakukan pe ngawasan terhadap ketataan penanggung jawab usaha dan/atau kegiatan terhadap peraturan perundang-undangan dan izin lingkungan, yang mengakibatkan terjadinya pencemaran dan/atau kerusakan lingkungan yang mengakibatkan hilangnya nyawa manusia”.

Sementara itu berikut adalah perbuatan terlarang yang dirumuskan dalam delik formil pada ketentuan pidana di dalam UU PPLH, selengkapnya adalah sebagai berikut:

"Melanggar baku mutu air limbah, baku mutu emisi, atau baku mutu gangguan; Melepaskan dan/atau mengedarkan produk rekayasa genetik ke media lingkungan hidup yang bertentangan dengan peraturan perundang-undangan atau izin lingkungan; Melakukan pengelolaan limbah B3 dan tidak melakukan pengelolaan; Melakukan dumping limbah dan/atau bahan ke media lingkungan tanpa izin; Memasukkan limbah ke dalam wilayah Negara Kesatuan Republik Indonesia; Melakukan pembakaran lahan; Melakukan usaha dan/atau kegiatan tanpa memiliki izin lingkungan; Menyusun amdal tanpa memiliki sertifikat kompetensi penyusun amdal; menerbitkan izin usaha dan/atau kegiatan tanpa dilengkapi dengan izin lingkungan; Memberikan informasi palsu, menyesatkan, menghilangkan informasi, merusak informasi, atau memberikan keterangan yang tidak benar yang diperlukan dalam kaitannya dengan pengawasan dan penegakan hukum yang berkaitan dengan perlindungan dan pengelolaan lingkungan hidup; Penanggung jawab usaha dan/atau kegiatan yang tidak melaksanakan paksaan pemerintah; dan Pejabat pengawas lingkungan hidup dan/atau pejabat penyidik pegawai negeri sipil".

Selain adanya delik materiil dan delik formil sebagaimana diuraikan diatas, dalam UU PPLH juga terapat kualifikasi delik lainnya, yaitu delik kesengajaan (opzet) dan kelalaian (culpa). Selengkapnya berikut delik yang dimaksud, dapat dicermati dalam tabel dibawah ini:

Tabel 2. Delik Kesengajaan dan Kealpaan

\begin{tabular}{cc}
\hline Kesengajaan & Kealpaan \\
\hline Pasal 98 & Pasal 99 \\
Pasal 100 & \\
Pasal 101 & \\
Pasal 102 & \\
Pasal 103 & \\
Pasal 104 & \\
Pasal 105 & \\
Pasal 106 & \\
Pasal 107 & \\
Pasal 108 & \\
Pasal 109 & \\
Pasal 110 & \\
Pasal 111 & \\
Pasal 112 & \\
Pasal 113 & \\
Pasal 114 & \\
Pasal 115 & \\
\hline
\end{tabular}


Pada pokoknya jaksa perlu diberikan informasi seputar kebijakan hukum pidana dalam menanggulangi tindak pidana di bidang lingkungan hidup dan tidak terbatas pada mengetahui adanya delik materiil, formil, kesengajaan dan culpa sebagaimana diuraikan diatas. Pemberian pemahaman ini penting untuk meningkatkan keahlian jaksa dalam melakukan penuntutan terhadap pelaku yang melakukan pelanggaran atas ketentuan pidana dalam UU PPLH.

\section{KESIMPULAN}

Kegiatan pengabdian kepada masyarakat yang memberikan pemahaman mengenai tindak pidana di bidang lingkungan hidup, sanksi pidana yang dapat dijatuhkan terhadap tindak pidana tersebut dan cara penindakan terhadap tindak pidana tersebut. Hal ini sangat penting untuk mempersiapkan para calon jaksa untuk menjadi jaksa yang memahami segala aspek kebijakan hukum pidana dalam menanggulangi tindak pidana di bidang lingkungan hidup.

\section{Ucapan Terima Kasih (Acknowledgement)}

Ucapan terima kasih kepada Lembaga Penelitian dan Pengabdian kepada Masyarakat (LPPM) Universitas Tarumanagara dan berbagai pihak yang telah membantu.

\section{REFERENSI}

Hiariej, Eddy O.S,. 2016. Prinsip-Prinsip Hukum Pidana, Edisi Revisi. Yogyakarta: Cahaya Atma Pustaka.

Lepa, Victory Prawira Yan. Pidana Pengawasan Dalam Sistem Pemidanaan Indonesia, Lex Administratum Volume II No.3 Tahun 2014.

Moh.Fadli., Et.al. 2016. Hukum \& Kebijakan Lingkungan. Malang: UB Press.

Nawawi, Arief Barda. 2002. Sari Kuliah Perbandingan Hukum Pidana. Jakarta: PT Raja Grafindo Persada.

Prakoso, Djoko. 1984. Tugas dan Peran Jaksa dalam Pembangunan. Jakarta: Ghalia Indonesia.

Prastowo, R.B. Budi. Tindak Pidana Lingkungan Sebagai Tindak Pidana Ekonomi Dalam Sistem Hukum Pidana Indonesia”, Jurnal Hukum Pro Justitia, Volume 24 No.1 Tahun 2006.

Rahmadi. 2014. Takdir. Hukum Lingkungan di Indonesia. Jakarta: Rajawali Pers.

Rangkuti, Siti Sundari. 2000. Hukum Lingkungan dan Kebijaksanaan Lingkungan Nasional. Surabaya: Airlangga University Press.

Ruslina, Eli. "Makna Pasal 33 Undang-Undang Dasar 1945 dalam pembangunan Hukum Ekonomi di Indonesia." Jurnal Konstitusi, Volume 9, Nomor 1, Tahun 2012.

"Penegakan Hukum Lingkungan Menurut Undang-Undang Nomor 32 Tahun 2009 Tentang Perlindungan dan Pengelolaan Lingkungan”, Kanun Nomor 52 Tahun 2010.

Sufiyatidan, Sri, Munsyarif Abdul Chalim. "Kebijakan Hukum PIdana dalam Menanggulangi Tindak Pidana Lingkungan Hidup", Jurnal Hukum, Volume 12 Nomor 3 Tahun 2017.

Supandriyo. 2019. Asas Kebebasan Hakim Dalam Penjatuhan Pidana Kajian Komprehensif Terhadap Tindak Pidana Dengan Ancaman Minimum Khusus Cetakan Ke-1. Jakarta: Arti Bumi Intaran.

Widayati. Lidya Suryani, "Ultimum Remedium dalam Bidang Lingkungan Hidup", Jurnal Hukum Ius Quia Iustum, Volume 22 Nomor 1 Tahun 2015.

Indonesia. Undang-Undang Dasar Republik Indonesia Tahun 1945, Cetakan Keenam, (Jakarta: Kepaniteraan dan Sekretariat Jenderal Mahkamah Konstitusi RI, 2016).

Indonesia. Undang-Undang Republik Indonesia Nomor 4 Tahun 1982 tentang KetentuanKetentuan Pokok Pengelolaan Lingkungan Hidup.

Indonesia. Undang-Undang Republik Indonesia Nomor 23 Tahun 1997 Tentang Pengelolaan Lingkungan Hidup. 


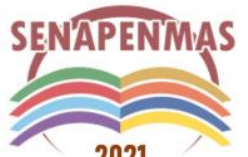

2021
Seminar Nasional Hasil Penelitian dan Pengabdian Kepada Masyarakat 2021

Pengembangan Ekonomi Bangsa Melalui Inovasi Digital Hasil Penelitian dan Pengabdian Kepada Masyarakat Jakarta, 21 Oktober 2021

Indonesia. Undang-Undang Republik Indonesia Nomor 32 Tahun 2009 Tentang Perlindungan dan Pengelolaan Lingkungan Hidup.

Indonesia. Undang-Undang Republik Indonesia Nomor 18 Tahun 2004 Tentang Kejaksaan.

Indonesia. Undang-Undang Republik Indonesia Nomor 12 Tahun 1995 Tentang Pemasyarakatan.

Indonesia. Surat Edaran Kejaksaan Agung Republik Indonesia Nomor B-3715/E/EJP/12/2012

Tentang Petunjuk terhadap perkara tindak pidana umum yang tetap (inkracht van gewijsde) tetapi belum dieksekusi 
Seminar Nasional Hasil Penelitian dan Pengabdian Kepada Masyarakat 2021

Pengembangan Ekonomi Bangsa Melalui Inovasi Digital Hasil Penelitian dan

Pengabdian Kepada Masyarakat

Jakarta, 21 Oktober 2021

(halaman kosong) 